\title{
ПРОБЛЕМЫ, СВЯЗАННЫЕ С РЕАЛИЗАЦИЕЙ КОНЦЕПЦИИ СОХРАНЕНИЯ КАПИТАЛА - БАЗИСА МСФО
}

\author{
(C) 2018 Петров Александр Михайлович \\ доктор экономических наук, профессор Департамента учета, анализа и аудита \\ Финансовый университет при Правительстве Российской Федерации \\ 125993, г. Москва, Ленинградский пр-т, д. 49 \\ E-mail:palmi@inbox.ru
}

Особую роль на современном этапе развития экономической теории в качестве комплексного показателя эффективности деятельности приобретает текущая стоимость капитала организации. Определение стоимости актива впервые было объяснено И. Фишером: «Стоимость капитального актива равняется сумме текущей стоимости всех будущих поступлений денежных потоков».

Ключевые слова: бухгалтерский учет, отчетность, концепция сохранения капитала, концепция сохранения стоимости, транспарентность.

Американский экономист И. Фишер в своих трудах «The Nature of Capital and Income» считал, что «Теория капитала заключается в том, что стоимость актива равна будущим денежным поступлениям, приведенным к текущей стоимости на основании соответствующей ставки дисконтирования» Что касается Джона Барр Уильяма, известный инвестор в своей книге, «Теория инвестиционной стоимости», писал, что «стоимость любой компании определяется входящими и исходящими потоками денежных средств, скорректированные по ставке дисконтирования». Специфическая трактовка капитала международными стандартами во многом определяет методологию учета конкретных фактов хозяйственной жизни, а также подход к предоставлению финансового положения организации в бухгалтерской отчетности.

Принципы модели оценки доходности капитальных активов (Capital Asset Pricing Model), основой которой служит анализ изменений доходности акций, обращающихся на фондовом рынке, были изложены в публикациях 1958 и 1961 годов профессорами Модильяни и Миллером: «стоимость любого актива - это текущая стоимость ожидаемого потока наличных поступлений».

Концепция сохранения (поддержания) капитала - базис МСФО. Капитал представляет собой разность между активами и обязательствами организации.

Основными целями анализа капитала являются следующими:

- определить источники формирования ка- питала, а также выявить последствия их изменений на финансовое положение организации;

- установить способность организации к сохранению (поддержанию) капитала;

- выявить правовые, финансовые и договорные ограничения в распределении текущей и накопленной нераспределенной прибыли. [1, с. 146].

Капитал организации рассматривается в следующих аспектах: учетном, финансовом и правовом.

Учетный аспект предполагает оценку первоначального вложения капитала, а также последующих изменений, которые связаны с дополнительными вложениями от чистой прибыли. После чего происходит наращивание или же уменьшение капитала.

Аспект данной проблемы находит свое отражение в концепции сохранения (поддержания) капитала, основанной на базисе МСФО и других учетных систем (GAAP USA и др.).

В основе концепции лежит следующее положение: для того чтобы защитить интересы кредиторов, а также для оценки собственниками полученного конечного финансового результата и его распределения, величина капитала субъекта должна сохраняться на неизменном уровне. Обязательным условием сохранения (поддержания) капитала является признание полученной в отчетном периоде прибыли.

В принципах подготовки и составления финансовой отчетности по МСФО используется две концепции поддержания капитала:

- оценка сохранения (поддержания) финан- 
сового капитала;

- оценка поддержания физического капитала.

Оценка поддержания финансового капитала основывается на анализе величины чистых активов и ее изменениях. Необходимо оценить действительно ли величина чистых активов организации сохраняется к концу анализируемого периода по сравнению с величиной на начало отчетного периода, с учетом снижения покупательной способности денежных средств.

На основании данного подхода прибыль считается полученной, если сумма чистых активов в конце периода превышает сумму чистых активов в начале периода за вычетом всех распределений и взносов собственников в течение периода.

Оценка поддержания физического капитала заключается в следующем: сохранение капитала к концу отчетного периода дает возможность восстановить материальные активы, которыми организация располагала в начале отчетного периода.

Экономический субъект самостоятельно выбирает метод оценки сохранения капитала - финансового или физического и зависит от интересов и потребностей пользователей. Если пользователей интересует поддержание инвестированного капитала с учетом изменения покупательской способности денег, то стоит применить концепцию сохранения (поддержания) финансового капитала. При интересе пользователей производственных возможностей и сохранение производственных активов, применяется концепция поддержания физического капитала.

Для того, чтобы выбрать определенную концепцию сохранения (поддержания) капитала организации проводят серьезную аналитическую работу.

Аналитические процедуры заключается следующим образом: ретроспективный анализ определение расходов на поддержание текущего уровня производительности, а также определение условий реального срока эксплуатации активов.

Перспективный анализ - выявление будущего уровня расходов на поддержание будущего уровня производительности.

Для дальнейшего понимания, какое влияние могут оказывать концепции сохранения (поддержания) капитала на финансовую отчетность, необходимо рассмотреть виды оценок, применяемые для определения стоимости активов и обязательств баланса организации. В табл. 1 рассмотрены четыре возможных подхода к оценке элементов финансовой отчетности на основании МСФО.

В российской системе бухгалтерского учета принята историческая стоимость за основу оценки активов и обязательств. Но стоит заметить, что в мировой практике применяются все указанные выше способы оценки активов и обязательств.

Финансовый аспект капитала заключается в общем требовании защиты интересов кредиторов - имущество должно превышать обязательства.

Правовой аспект капитала определяется остаточным принципом удовлетворения претензий собственников на активы и получаемые доходы. Необходимо учитывать как фактор финансового риска при принятии решений.

Рассмотрим показатели, которые характеризуют использование капитала, представленные

Таблица 1. Подходы к оценке элементов финансовой отчетности

\begin{tabular}{|l|l|}
\hline \multicolumn{1}{|c|}{ Подходы } & \multicolumn{1}{c|}{ Описание } \\
\hline Историческая стоимость & $\begin{array}{l}\text { Активы учитываются по справедливой стоимости на момент приобретения. } \\
\text { Обязательста учитываются по величине выгоды, полученной взамен на обяза- } \\
\text { тельство на момент возникновения обязательства. }\end{array}$ \\
\hline $\begin{array}{l}\text { Текущая рыночная } \\
\text { стоимость }\end{array}$ & $\begin{array}{l}\text { Активы учитываются по величине денежных средств или денежных эквива- } \\
\text { лентов, которая необхдима, чтобы приобрести активы в настоящий момент. } \\
\text { Обязательства учитываются по недисконтированной сумме денежных средств. }\end{array}$ \\
\hline Стоимость реализации & $\begin{array}{l}\text { Активы учитываются по величине денежных средств или денежных эквивален- } \\
\text { тов за минусом расходов на реализацию. Обязательства оцениваются по вели- } \\
\text { чине денег или денежных эквивалентов, которая необходима для выполнения } \\
\text { обязательства при обычных условиях ведения бизнеса. }\end{array}$ \\
\hline Приведенная стоимость & $\begin{array}{l}\text { Активы оцениваются по приведенной стоимости чистых будущих входящих } \\
\text { денежных потоков. Обязательства оцениваются по приведенной стоимости } \\
\text { чистых будущих исходящих денежных потоков. }\end{array}$ \\
\hline
\end{tabular}


в табл. 2.

Коэффициент покрытия процентов - финансовый показатель, соизмеряющий величину прибыли до выплаты процентов по кредиту и уплаты налогов (англ. EBIT, Earnings before interest and taxes) с издержками по выплате процентов.

Значение показателя считается нормальным от 3 до 4. Если значение коэффициента становится меньше 1 , то следует считать, что организация не создаёт достаточного денежного потока из операционной прибыли для обслуживания процентных платежей.

Финансовый рычаг показывает эффективное влияние использования заемного капитала организации на величину чистой прибыли.

Коэффициент финансового левериджа представляет собой отношение заемного средств организации к собственному капиталу. Данный коэффициент на прямую отражает уровень финансового риска организации.

Коэффициент дивидендных выплат - показатель для оценки стабильности и зрелости организации, а также дивидендную устойчивость. Данный коэффициент показывает долю прибыли организации, которая впоследствии идет на выплату дивидендов акционерам. Интерпретация показателя следующее: от $40 \%$ до $70 \%$ - оптимальное значение, менее $40 \%$ - невыгодное состояние для инвестора, более $70 \%$ - невыгодное состояние для организации.

Модели расчета ставки дисконтирования: сущность, значение и области применения. Решением проблемы выявления выгодности инвестиционных вложений содержит применение финансового механизма - дисконтирование.

Методика дисконтирования заключается в приведении будущих денежных потоков к настоящему моменты, который основана на понятии сложных процентов. Процесс является трудоёмким, так как дисконтирование включает в себя этапы, например, определение прогнозного и послепрогнозного периодов, расчет ставки дисконтирования, а также расчет текущих стоимостей будущих денежных потоков. Формула дис- контирования выглядит следующим образом:

$$
\mathrm{PV}=\mathrm{FV} /(1+\mathrm{i})^{\mathrm{n}} \text {, }
$$

где PV - текущая стоимость; FV - будущая стоимость; $i$ - ставка дисконтирования; $\mathrm{n}-$ число периодов.

Ставка дисконта является одним из ключевых параметров формулы дисконтирования. С точки зрения экономики, ставка дисконта норма доходности на вложенный капитал, которую требует инвестор.

Метод расчета ставки дисконта на основе модели средневзвешенной стоимости капитала (WACC - Weight average cost of capital) получил широкое распространение из-за использования во многих организациях не только собственного, но и заемного капитала.

Метод расчета ставки дисконтирования на основе средневзвешенной стоимости капитала впервые был применен учеными Модельяни и Миллером в 1958 году. Средневзвешенная стоимость капитала характеризует стоимость авансированного в деятельность организации капитала. Если уровень рентабельности принимаемых инвестиционных решений выше показателя WACC, то экономически мероприятия были бы оправданы. Данный показатель подвержен влиянию внутренних и внешних факторов. Степень воздействия подвергается изменениям со стороны организации в отношении следующих факторов, например, структура капитала, дивидендов, инвестиционной политики. Однако имеются факторы, которые не поддаются поправкам, такие как уровень процентных ставок, безрисковая процентная ставка.

Модель WACC приемлема не для всех организаций, например, организация не является открытым акционерным обществом и ее акции не продаются на фондовой бирже, но все же ее применяются в инвестиционном анализе, финансовом менеджменте.

Другой популярной моделью расчета ставки дисконтирования в мировой практике оценки стоимости инвестиций и бизнеса стала оцен-

Таблица 2. Показатели структуры капитала

\begin{tabular}{|c|c|}
\hline Показатели & Условное обозначение \\
\hline Коэффициент покрытия процента & ЕВІТ/Проценты к уплате \\
\hline Финансовый рычаг (ЕМ) & ТА/Е \\
\hline Коэффициент леверджа & (Долг. об-ва + Кратк. обяз-ва) / Собственный капитал \\
\hline Коэффициент дивидендных выплат & Дивиденды / чистая прибыль * $100 \%$ \\
\hline
\end{tabular}


ка капитальных активов CAPM (Capital Asset Pricing Model), основой которой служит анализ изменений доходности акций, обращающихся на фондовом рынке. В соответствии с приведенной моделью стоимость собственного капитала равна сумме безрисковой доходности и премии за риск, рассчитанной с использованием бета-коэффициента [4, с. 83].

Модель оценки САРМ была разработана экономистом, а впоследствии лауреатом Нобелевской премии по экономике Уильямом Шарпом и представлена в его книге 1970 года «Портфельная теория и рынки капитала».

Базисом данной модели служат два вида риска:

1) специфический, т.е. уникальный риск, присущий конкретному активу, который может быть диверсифицирован (изменен);

2) рыночный риск, которому подвержены все ценные бумаги, составляющие рыночный портфель, и который невозможно снизить путем диверсификации.

Формула расчета ставки дисконтирования на основе данного метода выглядит следующим образом:

$$
R=R f+\beta(R m-R f),
$$

где $\mathrm{R}$ - требуемая инвестором ставка дохода (на собственный капитал); Rf - безрисковая ставка дохода; $\beta$ - коэффициент бета - мера рыночного риска и отражает чувствительность доходности ценной бумаги к изменениям доходности рынка в целом; Rm - общая доходность рынка в целом (среднерыночного портфеля ценных бумаг).
Под безрисковой ставкой дохода понимается процент доходности, полученный от применения того или иного финансового инструмента при условии наличия нулевого кредитного риска.

Следовательно, мы приходим к выводу, что оценка активов и обязательств и отражение изменений капитала в финансовой отчетности в соответствии с концепцией сохранения (поддержания) капитала является самостоятельным решением организации.

В настоящее время при выборе той или иной концепции поддержания капитала организации отдают предпочтение финансовой концепции. Это объясняется следующим: акционеры заинтересованы в росте покупательной способности своих инвестиций, а также рост стоимости активов в результате переоценки улучшают показатели деятельности организации, цель бизнеса - наращивание стоимости инвестиций, а не поддержание текущей производительности при использовании физической концепции.

Наличие основных методов расчета ставки дисконтирования (WACC, CAMP) дает возможность организации выбрать наиболее подходящий метод с учетом специфики объекта оценки, возможность применения модели в конкретном случае, а также при наличии необходимой информации.

Важно учитывать условие организационно-правовой формы при выборе денежного потока на весь инвестированный капитал (при условии, что ставка дисконтирования рассчитывается по модели WACC) - публичное акционерное общество и возможность продажи акций на фондовом рынке.

\section{Библиографический список}

1. Петров А.М. Международные стандарты финансовой отчетности. Учебник / Москва, 2019. Сер. Высшее образование: Магистратура (ФУ)

2. Бабаев Ю.А., Петров А.М. Расчеты организации: учет, контроль и налогообложение. учебно-практическое пособие для студентов высших учебных заведений, обучающихся по специальности 080109 «Бухгалтерский учет, анализ и аудит» / Ю.А. Бабаев, А. М. Петров. Сер. Вузовский учебник. Москва, 2010.

3. Петров А.М., Мельникова Л.А. Затраты и расходы в системе бухгалтерского учета и налогообложения. Проблемы современной экономики. 2013. № 4 (48). С. 179-183.

4. Петров А.М. Организационный механизм контроля за движением дебиторской и кредиторской задолженности. Экономический анализ: теория и практика. 2006. № 18 (75). С. 54-62.

5. Бабаев Ю.А., Петров А.М. Бухгалтерский учет и контроль дебиторской и кредиторской задолженности. учеб.-практ. пособие / Ю.А. Бабаев, А.М. Петров. Москва, 2004.

6. Бабаев Ю.А. Теория бухгалтерского учета. учебник / Ю.А. Бабаев, А. М. Петров; под ред. Ю.А. Бабаева. Москва, 2011. (Изд.5-е, перераб. и доп.) 
7. Петров А.М. Контроль за движением дебиторской и кредиторской задолженности. Современный бухучет. 2004. № 9. С. 38.

8. Бабаев Ю.А., Друцкая М. В., Кеворкова Ж.А., Листопад Е. Е., Петров А. М. Бухгалтерский учет, анализ и аудит внешнеэкономической деятельности. учебник для студентов обучающихся по специальности 080109 «Бухгалтерский учет, анализ и аудит» / под редакцией Ю.А. Бабаева. Москва, 2010.

9. Мельникова Л.А., Петров А. М. Бухгалтерский учет финансовых резервов и оценочных обязательств. Монография. Москва. 2015.

10. Бабаев Ю.А., Петров А.М. Бухгалтерский учет в торговле и общественном питании. Учебное пособие. Москва. 2015. 